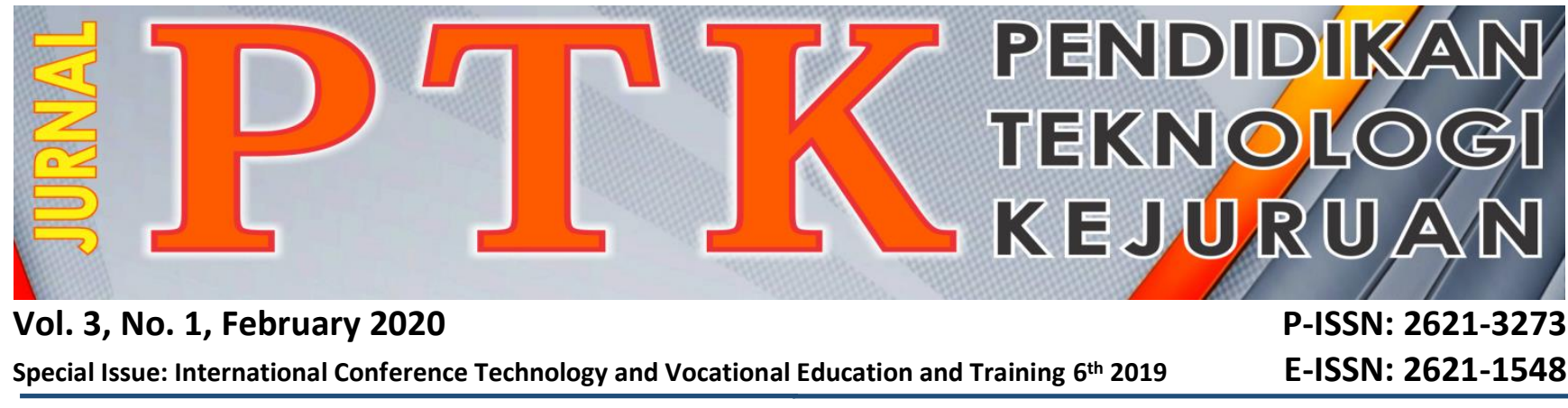

\title{
CONCEPT OF CURRICULUM EVALUATION IN EDUCATION PROGRAM OF ELECTRICAL ENGINEERING USING AUN-QA AS BENCHMARKING
}

\author{
Vice Pramutia Dolly ${ }^{1}$ and Riki Mukhaiyar ${ }^{2}$ \\ ${ }^{12}$ Postgraduate of the Technology and Vocational Education, Faculty of Engineering \\ Universitas Negeri Padang \\ "Corresponding author, e-mail: vicepramutia@gmail.com ${ }^{1}$
}

\begin{abstract}
Qualified graduates is supported by an efficient process of education, improvement of competence on an ongoing basis, and appropriate curriculum. The curriculum becomes an important part in education. Each educational institution graduates expect superior quality, good morals, knowledge and competence of skilled labor. Quality of qualified graduates will increase the demand of stakeholders to recruit workers in the industry related. It is necessary to implement a quality program in an effort to provide the best service for educational activities. This study discusses the program carried out by educational and vocational study program in electrical engineering (EEVE) achieve the goal to do assessment by AUN-QA (ASEAN University NetworkQuality Assurance) in evaluating the curriculum. AUN-QA aims to conduct quality assurance of courses that a member of AUN, as well as guiding and guide the university to improve and maintain the quality of the university. Researchers use qualitative research using the comparative method of ex-postfacto with the kind of correlational study. The study was conducted with data collection, such as observation, interviews, field observation and documentation study. This research resulted in the development of curriculum in vocational and educational courses in electrical engineering (EEVE), in terms of meeting the basic needs for qualified graduates, competent and professional in accordance with the standards of the AUN-QA. Through this research is expected to be a pattern for other courses to evaluate the curriculum for graduates scored an excellent, competent and qualified.
\end{abstract}

Keywords: Curriculum Evaluation, Quality Graduates, Criteria AUN-QA

Copyright (C) 2020 JPTK. All rights reserved

\section{INTRODUCTION}

The curriculum has a very important position in the learning process because the curriculum learners and educators have a reference and a guide in the learning process and are able to develop themselves so having a value in life. The curriculum is one of the important tools that guide education in teaching and learning activities. The curriculum is always evolving in line with the development of the theory and practice of education. Based on Law No. 12 of 2012 on Higher Education, stated that the curriculum is the right college, but further declared should refer to national standards (Article 35 paragraph 1) [1]. Based on the results of the study, obtained by several dimensions of understanding the curriculum. Ibrahim R. (2005) grouped into the three-dimensional curriculum, namely the curriculum as a substance, as a system of curriculum, and curriculum as a field of study. The first dimension looked at the curriculum as plan learning activities for students in college or as a set of goals to be achieved [2].

So the curriculum is a method of teaching and learning, program evaluation, administration time, number of rooms and the selection of subjects. The curriculum is dynamic, where there are always changes and always requires the development and improvement in accordance with the needs and accompany the changing times. Curriculum changes made by evaluating the curriculum is to give judgment based on agreed criteria and the data obtained from the field. As an example at a university, then do some form of data retrieval from alumni who are working and who do not work or even from students who are still active in lectures. 
From this data to do an evaluation of the study program[11].

There is an organization that is doing the quality assurance of the study programs AUN-QA. AUNQA (ASEAN University Network-Quality Assurance) Is a networking organization of universities in ASEAN that has the main objective to strengthen and expand cooperation in the field of higher education among ASEAN countries. AUN was established in November 1995. Office of the Permanent Secretariat was established in 2000 and located on the campus of Chulalongkorn University in Bangkok Thailand [3]. AUN Quality Assurance (AUN-QA) is one of the activities carried out by the AUN which aims to perform quality assurance program of study that are members of the AUN and push for the implementation of process improvements in an ongoing learning process. ASEAN University Network-Quality Assurance (AUN-QA) refers to International accreditation standards, drawn up by experts ASEAN Quality Assurance and led by the National University of Singapore. AUN member and Prodi have in-asses AUN.

There are 11 standard assessment of the AUNQA, namely (1) Expected Learning Outcome, (2) Program Specification, (3) Program Structure and Content, (4) Teaching and Learning Approach, (5) Student Assessment, (6) Academic Staff Quality, (7) Support Staff Quality, (8) Student Quality and Support, (9) Facilities and Infrastructure, (10) Quality Enhancement, and (11) Output [5]. Of the 11 criteria that will be the asses, the researchers made three criteria, namely Program Structure and Content as the basis to evaluate the curriculum. Where the evaluation of on-going curriculum education study program in electrical engineering.

Based on AUN-QA criteria, curriculum as a form of requests from stakeholders to place learning to provide accurate and relevant curriculum so that graduates have the competence in accordance with the needs of the workforce [6]. Stakeholders are individuals, group of people, community or society as a whole or partially with ties and interests of the company. Science and technology development is very rapid it should be anticipated by the institution in order to prepare students and graduates are ready to enter the world of work [7]. Information corporate social performance (including environmental) restated the need for information specific stakeholders and form the company's response to those needs [8].

For example, in the educational and vocational study program in electrical engineering should have education courses and engineering courses. Where graduates can share knowledge in an educational perspective and implements owned engineering science professionals based on need. This study evaluated the curriculum in vocational and educational courses in electrical engineering, based on criteria AUN-QA, where stakeholders are demanding curriculum appropriate to the needs of the social environment. So that graduates have a relevant curriculum and approved by professionals in the field of electrical engineering education.

Based on the above, it is necessary to conduct further research on the evaluation of the curriculum in Electrical Engineering Education courses Universitas Negeri Padang with AUN-QA as benchmarking. This research is used to evaluate the curriculum and is being applied to the study program in Electrical Engineering Education Universitas Negeri Padang to make AUN-QA criteria as the basis. To then see whether the courses have been compiled in a syllabus and Electrical Engineering Education RPS Universitas Negeri Padang are in accordance with the needs of stakeholders in the business world and the industrial world.

\section{METHODOLOGY}

In this study, researchers used qualitative research methods ex-post-facto with the kind of correlational studies, where research is conducted on the following facts that occurred in the field [9]. The study was conducted with data collection, such as observation, interviews, field observation and documentation study. The purpose of this research is to get a concept of evaluating the curriculum based on the criteria AUN-QA, so that later the curriculum can be said, as appropriate, or not in accordance with the needs of the job and what classes underlying appropriateness to the needs desired by a user graduates is one stakeholder Electrical Engineering Education courses.

Correlation method to do that is reviewing the relationship between curriculum and is being applied to the AUN-QA criteria, and see if the curriculum applied is appropriate or not in accordance with the three-AUN-QA criteria, namely Program Structure and Contents a basic reference. Then do the curriculum evaluation based AUN-QA standards to meet the needs of stakeholders in the business world and the industrial world. 


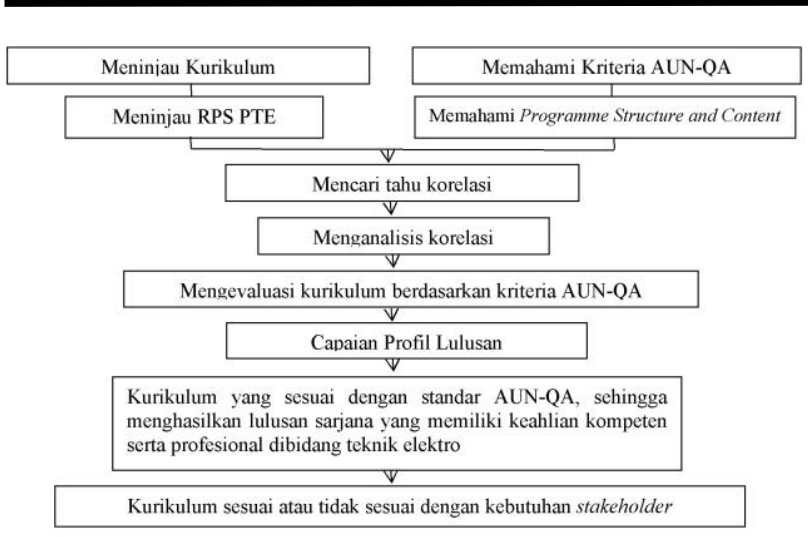

Figure 1. Research Methodology Flowchart

In this study, the first step is to review the curriculum, both in terms of syllabus and RPS in Electrical Engineering Education courses. Then from the results of the correlation will be sought to know whether the curriculum is already answered the questions offered by AUN-QA. This correlation will bring a draft evaluation of the curriculum of the AUN-QA as a reference. The purpose of the evaluation is to realize the curriculum according to the AUN-QA standards to produce graduates who are competent, superior, professionals and experts in the field. If it is so it can be reviewed whether the curriculum applied at Electrical Engineering Education courses is appropriate or not in accordance with the request of stakeholders.

\section{RESULT AND DISCUSSIONS}

Based on a study of the curriculum in Electrical Engineering Education courses at Universitas Negeri Padang, researchers found that every element of the curriculum three criteria, namely Program Structure and Content at AUN-QA is reached. This relates to stakeholder demand for graduates who are competent, superior, and professionals and experts in their fields. This means that courses offered in accordance with the needs of stakeholders. This is why graduates ready to plunge the spaciousness of the work, because it has been equipped with soft skills and hard skills are good and qualified. Research is also conducted with interviews with professors of electrical engineering education, teachers and principals of vocational schools, vocational education students, students of electrical engineering education, alumni who have worked in the industry, and alumni who have recently graduated from university. Research conducted on two vocational school teachers and alumni who have been working with the type of interview one on one with the number 3 . The data obtained related to the graduate profile EEVE in determining the Study Programs that researchers presented the results of studies in the form of 1) Competency EEVE. 2) Curriculum EEVE. 3) Scientific Applications of EEVE and 4) Performance EEVE graduates [10].

The interview results are summarized below:

Table 1. Interview Result from the stakeholders

\begin{tabular}{cll}
\hline Name & \multicolumn{1}{c}{ Work } & \multicolumn{1}{c}{ Interview result } \\
\hline $\begin{array}{c}\text { Informant } \\
1\end{array}$ & $\begin{array}{l}\text { Head of } \\
\text { the } \\
\text { vocationa } \\
1 \text { school }\end{array}$ & $\begin{array}{l}\text { Students must have } \\
\text { competencies that are } \\
\text { reliable in accordance } \\
\text { with their fields }\end{array}$ \\
& & $\begin{array}{l}\text { Competencies owned by } \\
\text { students as a form of } \\
\text { readiness and capital for } \\
\text { students to compete in } \\
\text { the industrial or corporate } \\
\text { world later. }\end{array}$ \\
& & $\begin{array}{l}\text { A graduate is required to } \\
\text { be able to apply his } \\
\text { educational knowledge in } \\
\text { vocational schools in } \\
\text { accordance with the } \\
\text { relevance of } \\
\text { knowledge. }\end{array}$ \\
& Electricit
\end{tabular}

- Students must be able to understand the curriculum that is being implemented at the vocational school.

- The application of MMK courses should be able to direct students to be able to make the revised edition KP K13, master the class well, language that is good and right in teaching theory and practice to students, as well as understanding the situation and condition of the school when students go to Educational Field Practice later.

Informant PTE BP - Graduates must have $32011 \quad$ superior hard and soft Alumni skills

- Balanced with the ability to develop knowledge, especially in the field of industry that continues to grow in line with current technological advances. 
From the research findings that investigators also get an overview of subjects and courses educational expertise into a single entity that can not be separated to give to students. Subject expertise to train students to hone skills they should have according to the scientific field. As well as educational courses, considered very necessary for students to further explore and understand how it should be an educator. This is done so that the student will be qualified graduates in the field. Graduates can be competent and professional to fit the needs of stakeholders.

In this study, the researchers conducted an evaluation Education courses curriculum of Electrical Engineering at the State Universitas Negeri Padang AUN-QA as benchmarking. Curriculum evaluation carried out with the aim of Electrical Engineering Education courses Universitas Negeri Padang to produce graduates who are qualified, competent, superior, and experts in the field. It deals with requests from stakeholders for the competence of graduates relevant to the study of science with the development of technology and industry. From the research data shows that the curriculum is applied to the Education Program of Electrical Engineering Universitas Negeri Padang according to three criteria, namely AUN-QA Program Structure and Content. The curriculum used in Electrical Engineering Education courses meets the needs of the industry and other stakeholders. So is the subject of expertise and educational subjects to be applied more deeply to the students, so the curriculum to meet the needs of vocational education is required in the era of industrial revolution 4.0, to produce competent human resources and quality as well as professionals in the field and satisfy the stakeholders in the labour market, especially the graduates of Electrical Engineering Education courses. To produce competent human resources and quality as well as professionals in the field. their field. And satisfy the stakeholders in the labour market, especially of graduates of Electrical Engineering Education courses. to produce competent human resources and quality as well as professionals in the field. their field. And satisfy the stakeholders in the labour market, especially of graduates of Electrical Engineering Education courses.

\section{CONCLUSION}

Based on research, it can be deduced that the correlation between the curriculum applied in electrical engineering education courses with three AUN-QA criteria, namely Program Structure and Content. From the results of the evaluation of the curriculum, where AUN-QA as a reference, educational and vocational study program in electrical engineering can fully meet the basic needs required by the stakeholders. So that the competency of graduates can be implemented according to the study of science. It is necessary to always make the evaluation and improvement of the curriculum relevant to the social environment, accompanied receive inputs from stakeholders that professionals in the field.

\section{REFERENCES}

[1] Presiden Republik Indonesia. Kerangka Kualifikasi Nasional Indonesia. Peraturan Presiden Republik Indonesia Nomor 8 Tahun 2012. Jakarta, Jakarta, Indonesia: Menteri Hukum dan Hak Asasi Manusia Republik Indonesia. 2012.

[2] Wulandari Tutik, Studi Analisis Kebutuhan Stakeholder Terhadap Lulusan Program Studi Pendidikan Teknik Elektro Universitas Negeri Padang, Skripsi, Padang, Universitas Negeri Padang.Agus Suprijono. Cooperative Learning: teori dan praktik. Yogyakarta: Pustaka Pelajar, 2018.

[3] Accreditation Commission for Senior Colleges and Universities. Handbook of Accreditation. Alameda, CA: Western Association of Schools and Colleges. 2001.

[4] Mulyono Amidi, Menyongsong Asesmen AUN-QA, Journal, pp.1-8. 2018.

[5] BAN-PT. Guide to AUN-QA Asessessment at Programme Level. Version 3.0. Bangkok: Chulalangkom University. 2016.

[6] Mukhaiyar R., Muskhir M., Hambali., and Vice PD., Curriculum Evaluation based on AUN-QA Criterion for the Case Study of the Electrical Engineering Vocational and Educational (EEVE) Study Program. International Journal, pp.1-4. 2019.

[7] Meldia Syafrina Putri, Pemetaan Kurikulum Program Studi Pendidikan Teknik Elektro Fakultas Teknik Universitas Negeri Padang Untuk Memaksimalkan Kompetensi Lulusan, Skripsi, Padang, Universitas Negeri Padang. 2018.

[8] Ayu Ardillah Anwar. Analisis Perspektif Stakeholder Terhadap Implementasi Corporate Social Responsibility (CSR). Skripsi. Makasar: Universitas Hasanudin. 2013.

[9] Hamid Darmadi, Metode Penelitian Pendidikan. (Bandung; Alfabeta, h. 223. 2011. 
[10] Curtis RF and Crunkilton Curriculum Development in Vocational and Technical education: Planning, Content, and Implementation (Allyn and Bacon Inc) Muhammad Nur. Pengajaran Langsung. Surayabaya: Pusat Sains dan Matematika sekolah UNESA, 2011.

[11] S. Syahril, N. Jalinus, R. A. Nabawi, and Y. Arbi, "The Create Skills of Vocational Students to Design a Product: Comparison Project Based Learning Versus Cooperative Learning-Project Based Learning," Adv. Soc. Sci. Educ. Humanit. Res., vol. 299, no. 5th UPI International Conference on Technical and Vocational Education and Training (ICTVET 2018) The, pp. 316-320, 2019. 